\title{
Genotoxic and cytotoxic effects of formic acid on human lymphocytes in vitro
}

\author{
Formik asidin insan lenfositleri üzerindeki in vitro genotoksik \\ ve sitotoksik etkisi
}

\author{
Pinar AKSU', \\ Gökhan NUR², \\ Süleyman GÜL', \\ Ayșe ERCIYAS ${ }^{1}$, \\ Zeynep TAYFA ${ }^{1}$, \\ Ertuğrul ALLAHVERDi ${ }^{4}$
}

\section{ABSTRACT}

Objective: Formic acid is an ubiquitous chemical constituent in the environment, being produced by sources as diverse as vegetation, ants, soil, vehicles, biomass burning, and photochemical reactions. The present work is focused on in vitro analysis of cytotoxic and genotoxic effects of formic acid, using cytogenetic tests such as the cytokinesis-block micronucleus assay (CBMN) and chromosomal aberration analysis, in human lymphocytes.

Method: This study was carried out using blood samples from healthy, non-smoking adults aged 18-22 years, of whom 10 were male and 6 were famale. Different concentrations $(0.07,0.1,0.2,0.3,0.4,0.5$, $0.8 \mathrm{mM}$ ) of formic acid was added to the lymphocyte culture test for chromosomal aberration (CA) analysis. Mitomycin-C $(0.3 \mathrm{mg} / \mathrm{ml})$ was used as the positive control. Human peripheral blood lymphocyte cells were treated with $20,40,60,80 \mathrm{mM}$ concentrations of formic acid for $48 \mathrm{~h}$. for the CBMN test. Mitomycin-C $(0.5 \mathrm{mg} / \mathrm{ml})$ was added to the Lymphocyte culture as a positive control. The present research was carried out to assess the cytotoxic and genotoxic effects of formic acid on human peripheral lymphocytes in vitro using the cytokinesis-block micronucleus assay (CBMN), as well as chromosomal aberration (CA) analysis.

\section{ÖZET}

Amaç: Formik asit, bitkiler, arılar, toprak, araçlar, gübre yanması ve fotokimyasal reaksiyonlar gibi çeșitli kaynaklarca üretilen ve çevrede yaygın olarak bulunan kimyasal bir bileșimdir. Mevcut çalıșma, insan lenfositlerinde sitokinez-blok mikronükleus tayini ve kromozomal aberasyon analizi gibi sitogenetik testler kullanarak formik asidin sitotoksik ve genotoksik etkilerinin in vitro analizine odaklanmıștır.

Yöntem: Bu çalışma 18-22 yaş arası 10'u erkek, 6'sı kadın sağlıklı, sigara kullanmayan yetișkinlerinden kan örnekleri kullanılarak gerçekleștirilmiștir. Lenfosit kültürüne kromozomal aberasyon (CA) testi için formik asidin farklı konsantrasyonları $(0,07$, $0,1,0,2,0,3,0,4,0,5,0,8 \mathrm{~mm})$ eklendi. Pozitif kontrol olarak mitomycin-C $(0,3 \mu \mathrm{g} / \mathrm{ml})$ kullanıldı. Sitokinez-blok mikronükleus tayini (CBMN) için, insan periferik kan lenfositleri 20, 40, 60, 80 mM derișimde formik asitle 48 saat ișleme tabi tutuldu. Lenfosit kültürüne, pozitif kontrol olarak mitomycin-C $(0,50 \mu \mathrm{g} / \mathrm{ml})$ eklendi. Bu araștırma, sitokinezblok mikronükleus tayinini (CBMN) ve kromozomal aberasyon (CA) analizini kullanarak in vitro insan periferal lenfositlerinde formik asidin sitotoksik ve genotoksik etkilerini değerlendirmek için yapılmıștır.

${ }^{1}$ Kafkas University, Faculty of Science and Arts, Department of Biology, KARS, TURKEY

${ }^{2}$ Gaziantep University, Vocational School of Higher Education in Islahiye, Department of Veterinary, GAZIANTEP, TURKEY

${ }^{3}$ Kafkas University, Faculty of Medicine, Department of General Surgery, KARS, TURKEY

${ }^{4}$ Kars State Hospital, Department of Orthopedic and Traumatology, KARS, TURKEY

$\begin{array}{lll}\text { Illetişim/Corresponding Author: Gökhan NUR } & \\ \text { Gaziantep University, Vocational School ofHigherEducation in Islahive, Department of Veterinary GAZIANTEP, TURKEY } & \text { Gelis Tarihi/Received : } 02.06 .2015 \\ \begin{array}{lll}\text { Tel : }+903428690300 & \text { E-posta/E-mail : gokhannur@gantep.edu.tr } & \text { Kabul Tarihi / Accepted : 03.12.2015 }\end{array}\end{array}$

DOI ID : 10.5505/TurkHijyen.2016.82621

Aksu P, Nur G, Gül S, Erciyas A, Tayfa Z, Diken-Allahverdi T, Allahverdi E. Genotoxic and cytotoxic effects of formic acid on human lymphocytes in vitro. Turk Hij Den Biyol Derg, 2016; 73(2): 111-20. 
Results: A significant increase was observed for induction of micronucleus frequency in all treatments of formic acid concentrations for $48 \mathrm{~h}$. comparing with the negative control and mitomycin C (MMC, $0.5 \mu \mathrm{g}$ / $\mathrm{ml}$ ) which was used as positive control. When compared with negative control and with mitomycin C (MMC, 0.3 $\mu \mathrm{g} / \mathrm{ml}$ ) which is used as positive control, it is observed that formic acid is rising the frequency of chromosomal aberration significantly at all appliance concantrations in $24 \mathrm{~h}$. The frequency of micronuclei and chromosomal aberrations increased in a dose dependent manner. The results showed that there were significant correlations between formic acid concentration and micronuclei frequency ( $r=0.92)$, numbers of necrotic cells $(r=0.95)$, and apoptotic cells $(r=0.91)$.

Conclusion: Our data provided evidence that there is a significant correlation between the concentration of formic acid and the following chromosomal aberrations: frequency of micronuclei, apoptotic cells, and necrotic cells in vitro.

Key Words: Formic acid, human lymphocyte culture, chromosomal aberration, micronucleus, cytotoxicity
Bulgular: Pozitif kontrol olarak kullanilan mitomisin C (MMC, 0,5 $\mathrm{gg} / \mathrm{ml}$ ) ile negatif kontrol karșılaștırıldığında formik asitin tüm dozları mikronükleus frekansını belirgin bir düzeyde arttırdığı gözlenmiștir. Pozitif kontrol olarak kullanılan mitomisin C (MMC, 0,3 $\mu \mathrm{g} / \mathrm{ml}$ )'nın negatif kontolle karșılaștırıldığında formik asidin 24 saatte tüm uygulama derișimlerinde, kromozomal aberasyonların sıklığını belirgin bir șekilde arttırdığı gözlenmiștir. Mikronükleus sıklığı ve kromozomal aberasyonlar, doza bağımlı olarak artmıștır. Sonuçlar formik asit konsantrasyonu, mikronükleus frekansı $(r=0,92)$, nekrotik hücrelerin sayısı $(r=0,95)$ ve apoptotik hücreler $(r=0,91)$ arasında anlamlı korelasyonların var olduğunu göstermektedir.

Sonuç: Verilerimiz, in vitro olarak formik asit konsantrasyonu ve mikronükleus frekansı, apoptotik hücreler ile nekrotik hücreler gibi kromozomal aberasyonlar arasında anlamlı bir korelasyon olduğu kanıtını sağlamıștır.

Anahtar Kelimeler: Formik asit, insan lenfosit kültürü, kromozomal aberasyon, mikronükleus, sitotoksisite

\section{INTRODUCTION}

Formic acid is the smallest member of the family of saturated monocarboxylic acids; it is a colorless liquid with a tangy odor and a density of 1.22 gram/ $\mathrm{cm}^{3}$. It dissolves in water, alcohol, and ether at all proportions. It burns when it comes in contact with skin. If it is heated to $160{ }^{\circ} \mathrm{C}$, it decomposes into carbon dioxide and hydrogen. It exists freely in nature in wood tar, nettles, ants, perspiration, urine and bouillon. Formic acid pollutes water and can spread through the air. Methyl alcohol is transformed into formaldehyde and formic acid by the body's metabolism; its toxicity is due to the acidosis resulting from the formic acid. As a result of this acidosis, nerve damage to the retina and, depending upon the degree of severity, blindness and eventually death may occur $(1,2)$. Most of the formic acid in tissues is oxidized via a tetrahydrofolic aciddependent pathway to $\mathrm{CO}_{2}$ and $\mathrm{H}_{2} \mathrm{O}$, such as in the liver, erythrocytes and kidneys (2). Literature on the carcinogenic and mutagenic effects of formic acid is quite limited. Tests of sister-chromatid exchange (SCE) performed on the typhimurium strains TA100, TA1535, TA97 and TA98 of Salmonella did not find it to be mutagenic. However, mutagenicity was reported in a test conducted on induction of sexlinked recessive lethal mutations as well as another study conducted on chromosomal aberrations $(3,4)$.

The present work is focused on in vitro analysis of cytotoxic and genotoxic effects of formic acid, using cytogenetic tests such as the cytokinesis-block micronucleus assay and chromosomal aberration analysis in human lymphocytes. 


\section{MATERIALS and METHODS}

This study was carried out using blood samples from healthy, non-smoking adults aged $18-22$ years, of whom 10 were male and 6 were famale. Donors provided written, informed consent at the time of donation for the use of their blood samples. Heparinized whole blood $(0.4 \mathrm{ml})$ was added to 5 $\mathrm{ml}$ chromosome medium (Biochrome). Cultures were incubated at $37{ }^{\circ} \mathrm{C}$ for $72 \mathrm{~h}$. Human lymphocytes were then exposed to different concentrations $(0.07,0.1,0.2,0.3,0.4,0.5,0.8 \mathrm{mM})$ of formic acid for $24 \mathrm{~h}$. A positive control (mitomycin-C), 0.3 $\mu \mathrm{g} / \mathrm{ml}$ ) was included in every experiment $(5,6)$. Lymphocytes were cultured in the dark for $72 \mathrm{~h}$, and metaphases were blocked during the last $2 \mathrm{~h}$ with colchicine at final a concentration of $0.06 \mu \mathrm{g} /$ $\mathrm{ml}$. Cells were collected by centrifuging ( $377 \mathrm{~g}, 10$ $\mathrm{min}$ ) and resuspended in a hypotonic $\mathrm{KCl}$ solution $(0.075 \mathrm{M})$ for $30 \mathrm{~min}$ at $37{ }^{\circ} \mathrm{C}$. At the end of this procedure, cells were centrifuged again and fixed in a cold methanol:acetic acid (3:1) mixture for $35 \mathrm{~min}$ at $+4{ }^{\circ} \mathrm{C}$. Following this process, cells were treated two times with fixative. Slides were then prepared by dropping concentrated cell suspensions onto the glass, followed by air drying. The air-dried slides were stained for 15-20 minutes with 5\% Giemsa stain $(\mathrm{pH}$ 6.8) prepared in a Sorensen buffer. One hundred metaphases per culture were analysed for the presence of chromosomal aberrations (CA). The number of CAs was obtained by calculating the percentage of metaphases at each concentration and treatment period that showed structural or numerical chromosome aberrations. Chromatid and chromosome breaks, chromosome exchange and chromatid unions, and polyploid cells were screened at all treatment concentrations $(5,7)$

For the micronucleus test in cultured human lymphocytes (CBMN), blood samples were added to 5 $\mathrm{ml}$ of chromosome medium (Biochrome). Cell cultures were incubated at $37{ }^{\circ} \mathrm{C}$ for $72 \mathrm{~h}$. Cytocalasin-B (6 $\mu \mathrm{g} / \mathrm{ml}$ ) was added to arrest cytokinesis at $44 \mathrm{~h}$ after culture initiation. Human lymphocytes were treated with different concentrations (20,40,60 and $80 \mathrm{mM}$ ) of formic acid for the CBMN test. Cells were exposed to the chemical for $48 \mathrm{~h}$ and harvested by centrifuging (167 $\mathrm{g}, 10 \mathrm{~min})$, and then the pellets were resuspended in a hypotonic solution of $0.075 \mathrm{M} \mathrm{KCl}$ for $5 \mathrm{~min}$ at $+4{ }^{\circ} \mathrm{C}$. The cells were centrifuged again and fixed in a cold methanol:acetic acid (3:1) mixture for $15 \mathrm{~min}$. The fixation procedure was administered three times. Formaldehyde $(1 \%)$ was added to the last fixative to preserve the cytoplasm. Slides were prepared by dropping concentrated cell suspensions onto the glass, followed by air drying. For CBMN analysis, staining was performed using $5 \%$ Giemsa $(\mathrm{pH}=6.8)$ prepared in a Sorensen buffer solution for 20-25 min. Slides were then washed in distilled water and dried at room temperature. Positive control (mitomycin- $C$ (MMC), $0.50 \mu \mathrm{g} / \mathrm{ml}$ ) was also maintained in the CBMN experiment (8).

Micronuclei were scored in 2000 binucleate lymphocytes for each subject (9). The nuclear division index (NDI) was evaluated using the following formula: $\mathrm{NDI}=(M 1+2(M 2)+3(M 3)+4(M 4)) / N$, where $M 1-M 4$ indicates the number of cells with 1 to 4 nuclei, and $\mathrm{N}$ indicate the total number of cells scored. The NDI of each cytochalasin B-treated culture was determined by screening 2000 interphase cells for the number of nuclei they contained (10).

Apoptotic and necrotic cells were identified with light microscopy according to morphological characteristics of the nucleus. In order to differentiate apoptotic cells from necrotic cells, we checked for the properties of necrotic cells, which exhibit a pale cytoplasm or loss of cytoplasm, numerous vacuoles, and a damaged/irregular nuclear membrane with a partially intact nuclear structure (9). 2000 cells were counted from each sample. The nuclear division cytotoxicity index $(\mathrm{NDCl})=(\mathrm{Ap}+\mathrm{Nec}+\mathrm{M} 1+2(\mathrm{M} 2)+$ $3(M 3)+4(M 4)) / N$ was evaluated according to Fenech (9), where $A p=$ the number of apoptotic cells, $\mathrm{Nec}=$ the number of necrotic cells, M1-M4 = the number of viable cells with 1-4 nuclei and $\mathrm{N}=$ the total number of cells scored. 
Statistical analyses of data were done using GraphPad InStat version 3.05 for Windows 95 (GraphPad Software, San Diego California USA). Chromosomal aberration frequencies in the cell cultures were analysed using Fisher's exact test. CBMN data were statistically analysed using the F-test for analysis of variance (ANOVA). The significance of differences between the negative control and the series of treatment groups were compared with Dunnett's t-test.

\section{RESULTS}

Compared to the other groups, an insignificant number of chromosomal aberrations was found in the metaphases obtained from the blood samples taken from the negative control group where no formic acid was added to the culture (Fig. 1A). Formic acid was administered to parallel cultures at doses of $0.8 \mathrm{mM}$
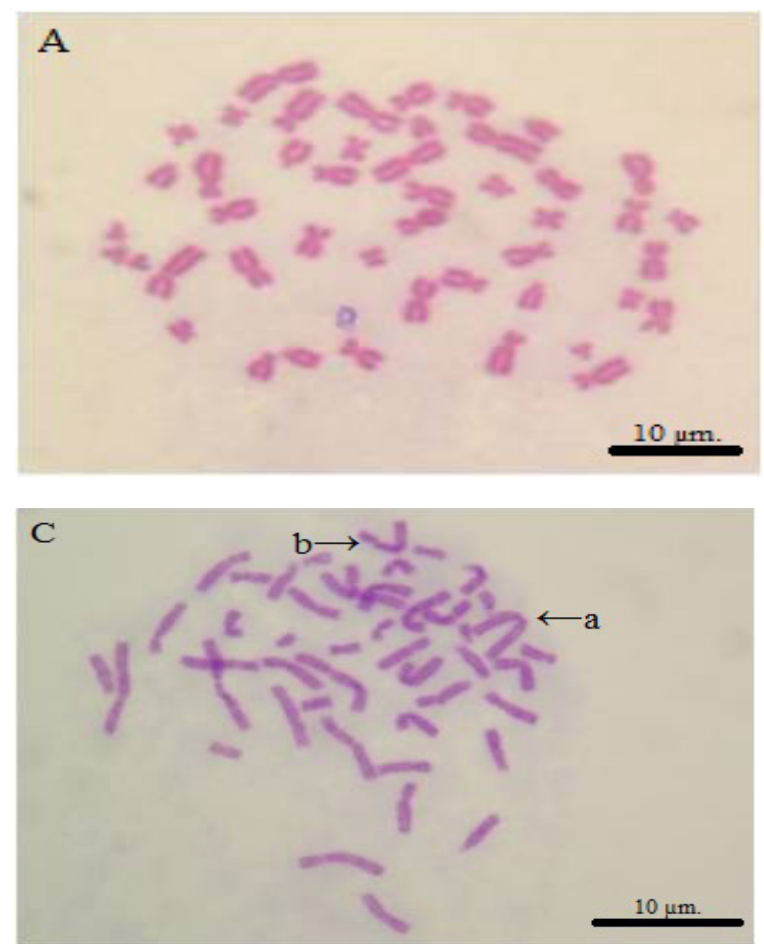

and lower $(0.07,0.1,0.2,0.3,0.4,0.5,0.8 \mathrm{mM})$. It was observed that division stopped fully in the culture where the number of metaphases was very low, and as a result the mitotic index was significantly decreased. After a trial was performed, it was determined that an activation period of 24 hours was suitable and that a longer period would prevent mitotic division. It was determined that the chromosomes condensed in the metaphases appeared filose and had a banded appearance (Fig. 1B). It was further observed that inhibition of cell division continued, but chromosomal anomalies in the metaphases were better visualized at an administered dose of $0.5 \mathrm{mM}$ formic acid (Fig. 1C). Banding in chromosomes and chromosome combinations were then observed more clearly. After treatment with $0.4 \mathrm{mM}$ formic acid, it was observed that mitosis was inhibited and that there were breaks in the chromatids and chromosomes in the metaphases (Fig. 1D).
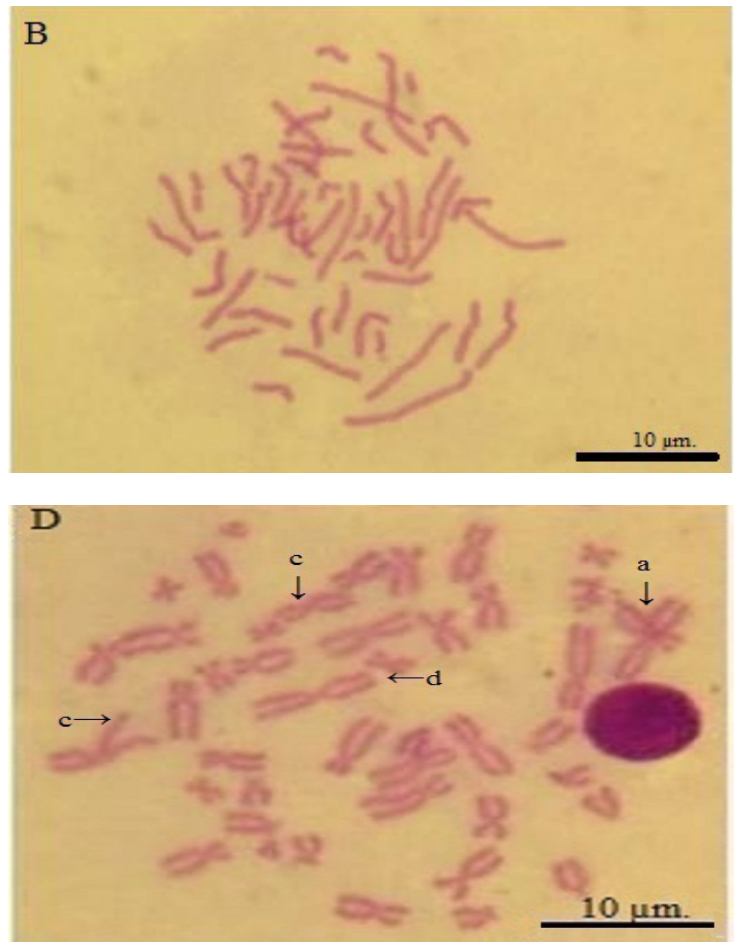

Figure 1. A. Metaphase plaque obtained from a normal individual. B. Metaphase plaque obtained from the culture that was administered $0.8 \mathrm{mM}$ of formic acid. C. Metaphase plaque obtained from the culture that was administered $0.5 \mathrm{mM}$ of formic acid: a. Chromosome combination, b. Chromosome break D. Metaphase plaque obtained from the culture that was administered $0.4 \mathrm{mM}$ of formic acid: a. Chromosome combination, c. Chromatide break, d. Chromatide combination. $(\times 1000$, Bar: $10 \mu \mathrm{m})$. 
A significant increase in the frequency of chromosomal aberrations was observed in some treatments with formic acid after $24 \mathrm{~h}$, compared to the negative control or treatment with mitomycin $C$, which was used as a positive control. The results obtained after treatment with $0.07 \mathrm{mM}$ formic acid were in line with the results obtained with the negative control. Polyploidy was observed at some formic acid treatment doses $(0.3,0.4 \mathrm{mM})$ and after treatment in the positive control (Table1).
Cytokinesis events were prevented by cytochalasin- $B$, and the frequencies of micronuclei and cell death (apoptosis and necrosis) were examined. Formic acid significantly increased the frequency of micronuclei in a dose dependent manner $(r=0.92)$. The nuclear division index (NDI) was calculated according to the number of nuclei present in the cells. Table 2 demonstrates that the NDI and nuclear division cytotoxicity index (NDCl) were significantly influenced by formic acid.

Table 1. Chromosome anomalies in human peripheral lymphocytes exposed formic acid for 24 hours

\begin{tabular}{|c|c|c|c|c|c|c|c|c|c|}
\hline \multirow{2}{*}{$\begin{array}{l}\text { Test } \\
\text { substance }\end{array}$} & \multicolumn{2}{|c|}{ Treatment } & \multicolumn{4}{|c|}{ Structural aberrations } & \multirow{2}{*}{$\begin{array}{c}\begin{array}{c}\text { Numerical } \\
\text { aberrations }\end{array} \\
\text { p }\end{array}$} & \multirow{2}{*}{$\begin{array}{l}\text { Frequency } \\
\text { of aberrant } \\
\text { cell } \pm \text { SEM (\%) }\end{array}$} & \multirow{2}{*}{$\begin{array}{c}\text { Mitotic index } \\
\quad \text { ISEM (\%) }\end{array}$} \\
\hline & Period (h) & Doses & ctb & csb & cse & $\mathrm{cu}$ & & & \\
\hline NC & 24 & 1 & 1 & 1 & - & - & - & $0.5 \pm 0.2$ & $4.3 \pm 0.3$ \\
\hline MMC $(\mu \mathrm{g} / \mathrm{ml})$ & 24 & 0.3 & 19 & 19 & 3 & 7 & 1 & $14.5 \pm 3.8^{*}$ & $1.7 \pm 1.2^{*}$ \\
\hline \multirow{6}{*}{$\begin{array}{l}\text { Formic acid } \\
(\mathrm{mM})\end{array}$} & \multirow{6}{*}{24} & 0.07 & 2 & 2 & - & 2 & - & $1.5 \pm 0.5$ & $4.3 \pm 1.2$ \\
\hline & & 0.1 & 3 & 3 & 1 & 4 & - & $2.7 \pm 0.6$ & $4.1 \pm 0.8$ \\
\hline & & 0.2 & 4 & 4 & 2 & 7 & - & $4.2 \pm 1.0$ & $4.0 \pm 1.0$ \\
\hline & & 0.3 & 7 & 7 & 2 & 13 & 1 & $9.7 \pm 4.5$ & $3.8 \pm 0.9^{*}$ \\
\hline & & 0.4 & 11 & 11 & 1 & 15 & 1 & $9.5 \pm 2.9$ & $3.5 \pm 0.5^{*}$ \\
\hline & & 0.5 & 12 & 12 & 3 & 18 & - & $11.3 \pm 3.0^{*}$ & $2.8 \pm 0.8^{*}$ \\
\hline
\end{tabular}

ctb: chromatid break, csb: chromosome break, cu: chromatid union, cse: chromosome exchange, nc: negative control (\%1 distilled water), MMC: $(0.3 \mu \mathrm{g} / \mathrm{ml}$ mitomycine-C (24 hours), p:polyploidy.

* $\mathrm{p}<0.05$ as compared to control. Fisher's Exact Test.

Table 2. The effects of formic acid on micronucleus frequency, nuclear division index, and nuclear cytotoxic division index in human lymphocytes cultures

\begin{tabular}{|c|c|c|c|c|c|c|c|c|c|c|}
\hline & \multicolumn{2}{|c|}{ Administration } & \multirow{2}{*}{$\begin{array}{l}\text { Number } \\
\text { of Cells } \\
\text { Counted }\end{array}$} & \multicolumn{4}{|c|}{$\begin{array}{l}\text { Distribution of } \mathrm{MN} \text { number } \\
\text { into Binuclear cells }\end{array}$} & \multirow{2}{*}{$\begin{array}{l}\text { MN/cell } \\
(\%) \pm S E M\end{array}$} & \multirow{2}{*}{ NDI } & \multirow{2}{*}{ NCDI } \\
\hline & Time (s) & Dose & & 1 & 2 & 3 & 4 & & & \\
\hline $\begin{array}{l}\text { Negative } \\
\text { Control }\end{array}$ & - & - & 2000 & 1 & 0 & 0 & 0 & $0.002 \pm 0.25$ & $1.981 \pm 0.34$ & $1.981 \pm 0.25$ \\
\hline PC (MMC) & 48 & $0.5 \mu \mathrm{g} / \mathrm{ml}$ & 2000 & 150 & 16 & 1 & 0 & $0.40 \pm 36.2$ & $1.332 \pm 0.83$ & $1.359 \pm 1.10$ \\
\hline \multirow{4}{*}{$\begin{array}{l}\text { Formic } \\
\text { acid }\end{array}$} & 48 & $20 \mathrm{mM}$ & 2000 & 7 & 1 & 1 & 1 & $0.02 \pm 1.50$ & $1.713 \pm 0.38^{*}$ & $1.731 \pm 0.48$ \\
\hline & 48 & $40 \mathrm{mM}$ & 2000 & 7 & 1 & 1 & 2 & $0.02 \pm 1.40$ & $1.678 \pm 0.55^{*}$ & $1.697 \pm 0.76$ \\
\hline & 48 & $60 \mathrm{mM}$ & 2000 & 9 & 3 & 2 & 2 & $0.04 \pm 1.63$ & $1.626 \pm 0.68^{*}$ & $1.667 \pm 0.47$ \\
\hline & 48 & $80 \mathrm{mM}$ & 2000 & 17 & 2 & 1 & 1 & $0.05 \pm 3.95$ & $1.592 \pm 0.78^{*}$ & $1.625 \pm 0.55$ \\
\hline
\end{tabular}

*Significantly different from the negative control $\mathrm{P}<0.05$ (Dunnett's t-test). NDI: Nuclear division index, NCDI: Nuclear cytotoxic division index, SEM: Standard error of the mean. 
$\mathrm{NDI}$ and NDCl values were lower than in controls. The lowest NDI values were observed in cultures treated with $80 \mathrm{mM}$ formic acid. All doses of formic acid administered increased micronuclei frequency and cell death to a statistically significant degree $(p<0.05)$ compared with the negative control group (Fig. 2A-G). There was a positive correlation between $M N$ frequency, the number of apoptotic cells $(r=0.91)$, and the number of necrotic cells $(r=$ 0.95) (Fig. 3A-C).

\section{DISCUSSION}

One of the most sensitive methods used to determine the genotoxic risks of mutagens and carcinogensisassessing the frequency of chromosome aberration (CA) in peripheral blood lymphocytes $(11,12)$. Chromosome aberrations occur due to damage at the DNA level. For instance, chromosome breaks may be caused by unrepaired double chain breaks in the DNA, and the emergence of chromosomes with a new structure may be caused by the false repair of chain breaks in the DNA (13). Due to the fact that the mechanisms by which chromosomal anomalies emergence resemble each another in different tissues, the level of anomalies in lymphocytes is considered to be an indication of the level of anomalies in other tissues that tend to be cancerous; thus it is also an indicator of cancer risk $(14,15)$. A high frequency of chromosomal aberrations may give an advance indication that there is a high risk of cancer, regardless of the reason that the increase in chromosome anomalies was triggered. Anomalies of both the chromatid type and chromosome type are indicators of cancer risk. However, there is evidence that chromosome anomalies are better determinants than chromatid anomalies $(15,16)$.

Another type of cytogenetic method used to determine genotoxicity and carcinogenicity is the micronucleus $(M N)$ test $(17,18)$. According to Bonassi et al. (19), a high $M N$ frequency in

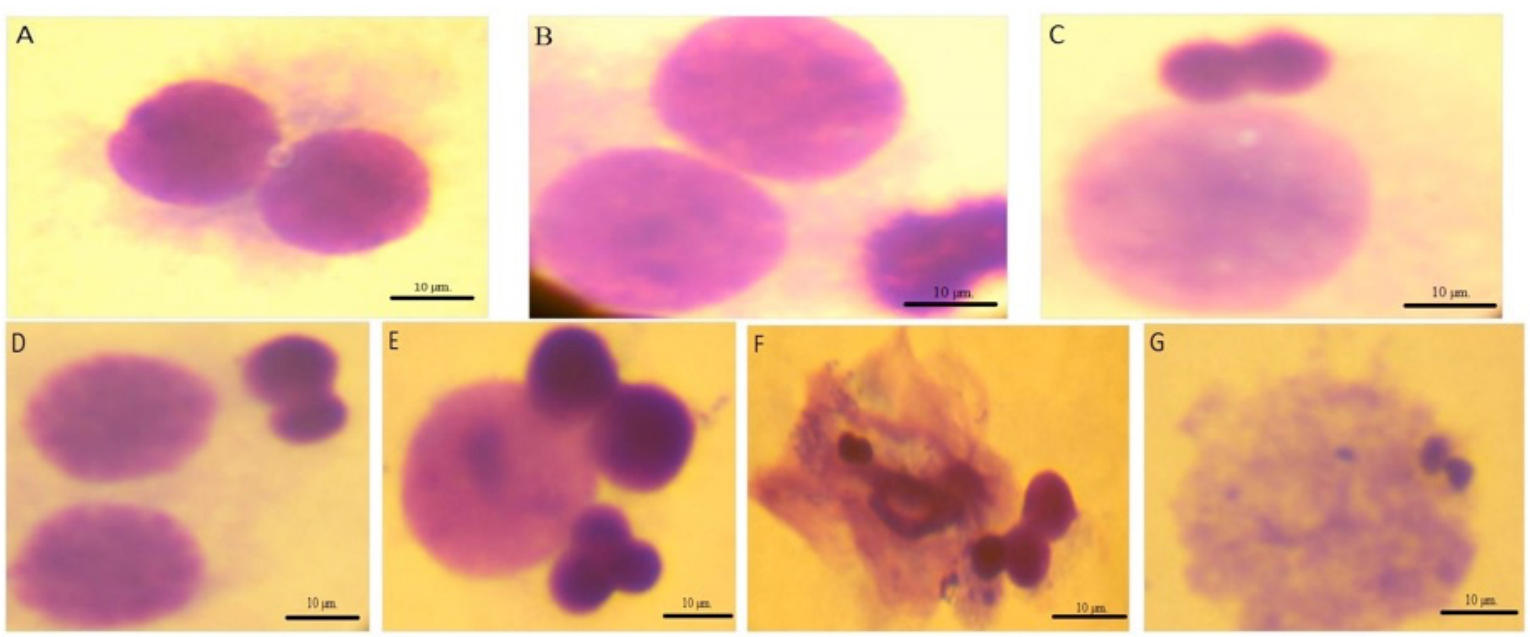

Figure 2. Micronucleus creations lymphocyte culture which was administered different doses of formic acid A. Double nucleus cell in which the normal cytokinesis was inhibited. B. Double nucleus cell containing one micronucleus the cytokinesis of which was inhibited ( $20 \mathrm{mM}$ formic acid, process of 48 hours). C. Single nucleus cell containing two micronuclei in which the cytokinesis was inhibited ( $40 \mathrm{mM}$ formic acid, process of 48 hours). D. Double nucleus cell containing two micronuclei in which the cytokinesis was inhibited (60 mM formic acid, process of 48 hours). E. A cell with multi micronuclei in which the cytokinesis was inhibited and which is entering apoptosis ( $80 \mathrm{mM}$ formic acid, process of 48 hours). F. An apoptotic cell ( $80 \mathrm{mM}$ formic acid, process of 48 hours). G. Necrotic cell with a pale cytoplasm, many small vacuoles and a cytoplasmic and nuclear membrane with corrupted structure ( $80 \mathrm{mM}$ formic acid, process of 48 hours). ( $\times 1000$, Bar: $10 \mu \mathrm{m})$. 
peripheral blood lymphocytes indicates a risk of cancer in humans. When the cytokinesis blockage micronucleus method was developed by Fenech and Morley (20), researchers began to examine the $M N$ in cells which have completed nuclear division. $M N$ are the small nuclei found apart from their sister nucleus, created during telophase due to the breaks in non-centric chromosomes or chromatid, and to the backwardness of all chromosomes or chromatides (slow chromosomes) (21). In a study that investigated the cytogenetic effect using the micronucleus, chromosomal aberration and sister chromatid exchange method, mercuric chloride has been shown to be a clastogenic chemical because of the variety of chromosomal abnormalities and the increase in the number of micronucleated cells (22).

Formic acid is used in carbonated drinks, fruit, vegetables and canned food as a preservative substance. Furthermore, it is commonly employed by honey producers to combat parasitic Varroa destructor mites in bee colonies (23). In one of their studies, Morita et al. tested the relationship between the clastogenic activities

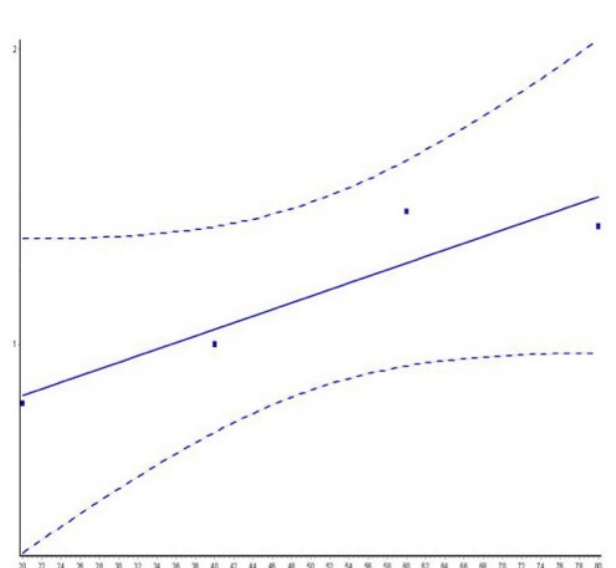

A.

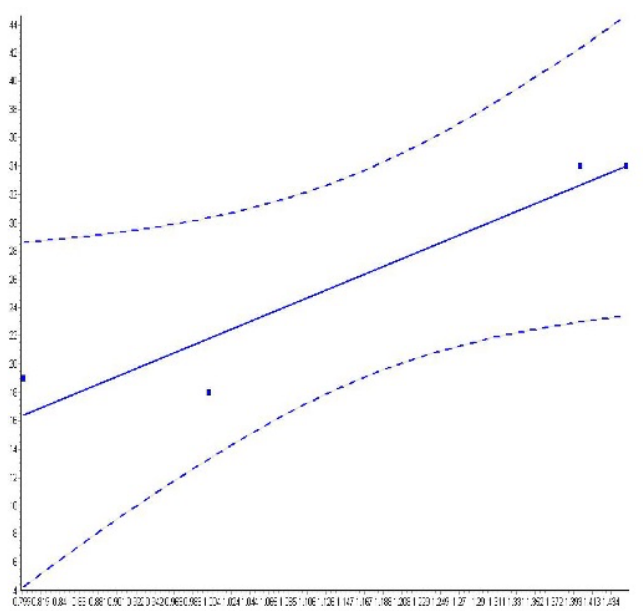

C.

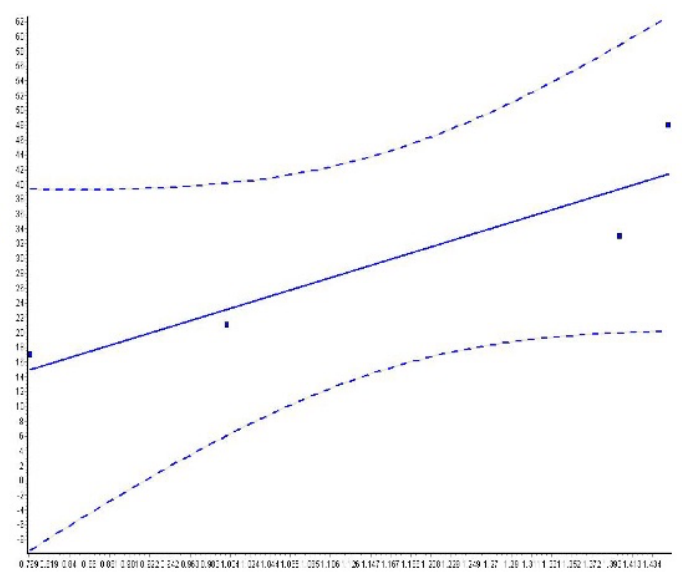

B.

Figure 3. A. Formic acid dose-micronucleus regression charts. B. MN frequency-apoptotic cell regression charts $(r=0.91, p<0.05)$. C. Micronucleus frequency-necrotic cell regression charts $(r=0.95, p<0.05)$. 
of formic acid and the $\mathrm{pH}$ of the medium using Chinese hamster ovary $\mathrm{K} 1$ cells. That study reported that acids stimulated chromosomal aberrations in the media with an original $\mathrm{pH}$ of 6. It was also determined that 12-16 mM concentrations of this acid exhibited toxicity in the media at $\mathrm{pH} 5.7$ or lower (3). In a study of the inhibitory effect of a mixture of propionic acid and formic acid on Salmonella pullorum, it was reported that the mixture of propionic acidformic acid caused a significant decrease in the number of colonies in the culture compared to the control (24). DNA adductions formed by various chemicals play an important role in cancer initiation. Wang et al. (25) reported that formic acid caused DNA adducts as well as hemoglobin $(\mathrm{Hb})$ adducts in mice.
The frequency of micronuclei in peripheral blood lymphocytes is used as a biomarker for chromosome damage (9). The doses that were used in the $M N$ and chromosomal aberration studies were different. The chromosomal aberration treatment dose is typically lower than the MN dose (26-28). However, in some studies the dose producing $M N$ was found to be equal to the dose causing chromosomal aberrations $(29,30)$. In our study, the dose that caused chromosomal aberrations was found to be lower than that which leads to micronuclei formation.

Conclusion: Our data provide evidence that there is a significant correlation between the concentration of formic acid and the following chromosomal aberrations: frequency of micronuclei, apoptotic cells and necrotic cells in vitro.

\section{ACKNOWLEDGEMENTS}

This study was conducted with support from the Kafkas University Scientific and Technological Research Fund (Project No: FEF-26).

Note: This study was previously presented at the 3rd National Veterinary Pharmacology and Toxicology Congress (With International Contribution), 29 September - 2 October 2010, pp.: 88-89, Aydın, Turkey.

\section{CONFLICTS of INTEREST}

The authors declare no conflicts of interest. 


\section{REFERENCES}

1. Barceloux DG, Bond GR, Krenzelok EP, Cooper H, Vale JA. American Academy of Clinical Toxicology practice guidelines on the treatment of methanol poisoning. Clin Toxicol, 2002; 40: 415-46.

2. Boeniger MF. Formate in urine as a biological indicator of formaldehyde exposure-a Review. Am Ind Hyg Assoc J, 1987; 48: 900-8.

3. Morita T, Takeda K, Okumura K. Evaluation of clastogenicity of formic acid, acetic acid and lactic acid on cultured mammalian cells. Mutation Research/Genetic Toxicology, 1990; 240 (3): 195-202.

4. Tephly TR. The toxicity of methanol. Life Sci, 1991; 48 (11): 1031-41.

5. Lazutka JR, Mierauskiene J, Slapsyte G, Dedonyte V. Genotoxicity of dill (Anethum graveolens L.), peppermint (Mentha x piperita L.) and pine (Pinus sylvestris L.) essential oils in human lymphocytes and Drosophila melanogaster. Food Chem Toxicol, 2001; 39: 485-92.

6. Roncada T, Vicentini VEP, Mantovani MS. Possible modulating actions of plant extracts on the chromosome breaking activity of $M M C$ and Ara-C in human lymphocytes in vitro. Toxicol in Vitro, 2004; 18: 617-22.

7. Yuzbasioglu D, Celik M, Yilmaz S, Unal F, Aksoy H. Clastogenicity of the fungicide a fugan in cultured human lymphocytes. Mutat Res-Gen Tox En, 2006; 604 (1-2): 53-9.

8. Demsia G, Vlastos D, Goumenou M, Matthopoulos DP. Assessment of the genotoxicity of imidacloprid and metalaxyl in cultured human lymphocytes and rat bone-marrow. Mutat Res-Gen Tox En, 2007; 634: $32-9$

9. Fenech M, Crot J, Turner J, Brown S. Necrosis, apoptosis, cytostasis and DNA damage in human lymphocytes measured simultaneously within the cytokinesis-block micronucleus assay: description of the method and results for hydrogen peroxide. Mutagenesis, 1999; 14: 605-12.

10. Eastmond DA, Tucker JD. Identification of aneuploidy-inducing agents using cytokinesisblocked human-lymphocytes and an antikinetochore antibody. Environ Mol Mutagen, 1989; 13 (1): 34-43.
11. Carrano AV, Natarajan AT. Considerations for population monitoring using cytogenetic techniques. Mutation Research/Genetic Toxicology, 1988; 204: 379-406.

12. Hagmar L, Brogger A, Hansteen IL, Heim S, Hogstedt B, Knudsen L, et al. Cancer risk in human predicted by increased levels of chromosomal aberrations in lymphocytes: Nordic study group on the health risk of chromosome damage. Cancer Res, 1994; 54 (11): 2919-22.

13. Savage JRK. Update on target theory as administered to chromosomal aberrations. Environ Mol Mutagen, 1993; 22: 198-207.

14. Albertini RJ, Anderson D, Douglas GR, Hagmar L, Hemminki K, Merlo F, et al. IPCS guidelines for the monitoring of genotoxic effects of carcinogens in humans. Mutat Res-Rev Mutat, 2000; 463: 111-72.

15. Boffetta P, Van der Hel O, Norppa H, Fabianova E, Fucic A, Gundy S, et al. Chromosomal aberrations and cancer risk: Results of a cohort study from central europe. Am J Epidemiol, 2007; 165: 36-43.

16. Norppa H, Bonassi S, Hansteen IL, Hagmar L, Stromberg U, Rossner P, et al. Chromosomal aberrations and SCEs as biomarkers of cancer risk. Mutat Res-Fund Mol M, 2006; 600(1-2): 37-45.

17. Fenech M. Biomarkers of genetic damage for cancer epidemiology. Toxicology, 2002; 181-182: 411-6.

18. Heddle JA, Cimino MC, Hayashi M, Romagna F, Shelby MD, Tucker JD, et al. Micronuclei as an index of cytogenetic damage: Past, present, and future. Environ Mol Mutagen, 1991; 18 (4): 277-91.

19. Bonassi S, Znaor A, Ceppi M, Lando C, Chang WP, Holland N, et al. An increased micronucleus frequency in peripheral blood lymphocytes predicts the risk of cancer in humans. Carcinogenesis, 2007; 28 (3): 625-31.

20. Fenech M, Morley AA. Measurement of micronuclei in lymphocytes. Mutation Research/Environmental Mutagenesis and Related Subjects, 1985; 147: 29-36.

21. Surralles J, Xamena N, Creus A, Marcos R. The suitability of the micronucleus assay in human lymphocytes as a new biomarker of excision repair. Mutation Research/Genetic Toxicology, 1995; 342: 43-59. 
22. Mahboob S, Al-Balwai HFA, Al-Misned F, Ahmad $Z$. Investigation on the genotoxicity of mercuric chloride to freshwater Clarias gariepinus. Pak Vet J, 2014; 34 (1): 100-3.

23. Fries I, Rosenkranz P. Number of reproductive cycles of Varroa jacobsoni in honey bee colonies. Exp Appl Acarol, 1996; 20: 103-12.

24. Al-Tarazi YH, Alshawabkeh K. Effect of dietary formic and propionic acids on Salmonella pullorum shedding and mortality in layer chicks after experimental infection. J Vet Med Infect Dis Vet Public Health, 2003; 50: 112-7.

25. Wang HF, Xu LH, Sun HF, Xue B, Liu YF, Peng S, et al. High binding of formic acid to biomacromolecules in mice. Nucl Instrum Meth B, 2004; 223: 745-9.

26. Celikler S, Yildiz G, Vatan O, Bilaloglu R. In vitro antigenotoxicity of Ulva rigida C. Agardh (Chlorophyceae) extract against induction of chromosome aberration, sister chromatid exchange and micronuclei by mutagenic agent MMC. Biomed Environ Sci, 2008; 21: 492-8.
27. Ogura H, Takeuchi T, Morimoto K. A comparison of the 8-hydroxydeoxyguanosine, chromosome aberrations and micronucleus techniques for the assessment of the genotoxicity of mercury compounds in human blood lymphocytes. Mut ResRev Gen Toxicol, 1996; 340: 175-82.

28. Panneerselvam N, Sinha S, Shanmugam G. Genotoxicity of the herbicide fluchloralin on human lymphocytes in vitro: chromosomal aberration and micronucleus tests. Mutation Research/Genetic Toxicology, 1995; 344: 69-72.

29. Anwar WA, Khalil MM, Wild CP. Micronuclei, chromosomal-aberrations and aflatoxin-albumin adducts in experimental-animals after exposure to aflatoxin B-1. Mut Res/Gen Toxicol, 1994; 322 : 61-7.

30. Buyukleyla M, Rencuzogullari E. The effects of thymol on sister chromatid exchange, chromosome aberration and micronucleus in human lymphocytes. Ecotox Environ Safe, 2009; 72: 943-7. 